\title{
Analisis pengaruh promosi dan margin terhadap keputusan pengambilan kredit kepemilikan rumah (KPR) syariah
}

\author{
Donni Pratama, Nasikh* \\ Universitas Negeri Malang, Jl. Semarang No. 5 Malang, Jawa Timur, Indonesia \\ *Penulis korespondensi, Surel: nasikh.fe@um.ac.id
}

Paper received: 5-7-2021; revised: 23-7-2021; accepted: 30-7-2021

\begin{abstract}
Bank Indonesia's Monetary and Fiscal Statistics data shows that financing provided by all types of banks in Indonesia increased by Rp. 504.494 billion in 2019 to Rp 513.528 billion in October 2020. Banking in Indonesia that has a focus in the Home Ownership Credit sector is Bank Syariah Indonesia with both Conventional and Sharia system. This study uses a descriptive quantitative approach due to the aspect of objective variable measurement with numbers in analyzing data using statistical procedures. The nature of this study is a correlation meaning that this study will look for the influence of promotion and also margin on sharia home ownership credit (HOM) decision making. Based on the research that has been done, it can be concluded that:(1) There is a significant influence between the promotion of sharia home ownership loan (HOM) decision at Bank Syariah Indonesia SoekarnoHatta Malang Branch. This is evidenced by the existence of customers who take a mortgage after learning of the promotion from the bank. (2) Variable $\mathrm{x} 2$ margin has no effect on sharia mortgage decision making due to what happens in the field of respondents choosing to take HOM due to subsidies from the government. (3) There is a significant influence between promotion and margin on sharia home ownership credit decision making at Bank Syariah Indonesia Soekarno Hatta Branch.
\end{abstract}

Keywords: promotion; margin; consumer behavior; sharia mortgage

\begin{abstract}
Abstrak
Data Statistik Moneter dan Fiskal Bank Indonesia menunjukan pembiayaan yang diberikan oleh seluruh jenis Bank yang ada di Indonesia mengalami peningkatan yaitu sebesar Rp. 504,494 Miliar di Tahun 2019 meningkat menjadi Rp 513,528 Miliar pada Oktober Tahun 2020. Perbankan di Indonesia yang memiliki fokus di sektor Kredit Pemilikan Rumah adalah Bank Syariah Indonesia baik dengan sistem Konvensional maupun Syariah. Penelitian ini menggunakan pendekatan kuantitatif deskriptif dikarenakan aspek pengukuran variabel secara objektif dengan angka dalam menganalisis data menggunakan prosedur statistika. Sifat penelitian ini adalah korelasi artinya penelitian ini akan mencari ada tidaknya pengaruh antara promosi dan juga margin terhadap keputusan pengambilan kredit kepemilikan rumah (KPR) Syariah. Berdasarkan penelitian yang telah dilakukan, dapat disimpulkan bahwa: (1) Terdapat pengaruh yang signifikan antara promosi terhadap keputusan pengambilan kredit kepemilikan rumah (KPR) syariah di Bank Syariah Indonesia Cabang SoekarnoHatta Malang. Hal ini dibuktikan dengan adanya nasabah yang mengambil KPR setelah mengetahui promosi dari bank tesebut. (2) Variabel $\mathrm{x} 2$ margin tidak berpengaruh terhadap pengambilan keputusan KPR Syariah disebabkan hal yang terjadi di lapangan responden memilih mengambil KPR dikarenakan subsidi dari pemerintah. (3) Terdapat pengaruh signifikan antara promosi dan margin terhadap pengambilan keputusan kredit kepemilikan rumah syariah di Bank Syariah Indonesia Cabang Soekarno Hatta.
\end{abstract}

Kata kunci: promosi; margin; perilaku konsumen; KPR syariah

\section{Pendahuluan}

Lembaga keuangan syariah di Indonesia telah berkembang dengan pesat. Hal ini menyebabkan banyak pihak ingin mengetahui apa perbedaan yang mendasar antara lembaga keuangan syariah dengan lembaga keuangan konvensional, perbedaannya terletak pada akad atau transaksinya. Produk apapun yang dihasilkan perbankan, termasuk didalamnya 
perbankan syariah, tidak akan terlepas dari transaksi yang dalam istilah disebut dengan akad. (Hak, 2011). Perbankan syariah sama seperti perbankan konvensional lainya di Indonesia adalah lembaga intermediary yang berfungsi mengumpulkan dana dari dan menyalurkan kepada masyarakat dalam bentuk pemberian fasilitas pembiayaan. Sehubungan dengan fungsi bank sebagai intermediary tersebut dalam kaitannya dengan penyaluran dana masyarakat atau pembiayaan berdasarkan prinsip syariah, bank syariah menanggung resiko. (Dahlan, 2012)

Pada umumnya yang dimaksud dengan bank syariah adalah lembaga keuangan yang usahanya memberikan kredit dan jasa - jasa lainnya dalam lalu lintas pembayaran serta peredaran uang yang beroperasi disesuaikan dengan prinsip - prinsip syariah. (Setianingtyas, 2016). Pembiayaan berdasarkan prinsip syariah adalah penyediaan uang atau tagihan yang dipersamakan dengan itu berdasarkan persetujuan atau kesempatan pinjam meminjam antara bank dengan pihak lain yang mewajibkan pihak yang membiayai untuk mengembalikan uang atau tagihan tersebut setelah jangka waktu tertentu dengan imbalan atau bagi hasil. (Muhammad, 2014). Penghimpunan dana dari masyarakat perlu dilakukan dengan cara - cara tertentu sehingga efisien dan dapat disesuaikan dengan rencana penggunaan dana tersebut. (Faiqah, 2013).

Sejalan dengan semakin berkembangnya kegiatan pembangunan di Indonesia dan dengan jumlah penduduk yang semakin meningkat, pemerintah berusaha untuk selalu meningkatkan kesejahteraan penduduk melalui pembangunan di berbagai sektor, salah satu sektor yang terpenting adalah masalah mengenai perumahan. Dengan pertumbuhan penduduk yang semakin pesat namun lahan yang tersedia semakin terbatas dapat mengakibatkan tingginya harga tanah dan rumah. Dengan ini perbankan di Indonesia mendapatkan inspirasi dengan mengadakan Kredit Pemilikan Rumah (KPR), dimana akan sangat membantu masyarakat untuk mempunyai rumah atau hunian yang diimpikan. Produk pembiayaan KPR yang digunakan dalam perbankan syariah memiliki berbagai macam perbedaan dengan KPR di perbankan konvensional. Hal ini merupakan implikasi dari perbedaan prinsipal yang diterapkan perbankan syariah dan perbankan konvensional, yaitu konsep bagi hasil dan kerugian (profit and loss sharing) sebagai pengganti sistem bunga perbankan konvensional. Dalam produk pembiayaan pemilikan rumah ini, terdapat beberapa perbedaan antara perbankan syariah dan perbankan konvensional, diantaranya adalah: pemberlakuan sistem kredit dan sistem mark up, kebolehan dan tidak kebolehan tawar menawar (bargaining position) antara nasabah dengan bank prosedur pembiayaan dan lain sebagainya (Haris, 2007).

Pengelolaan dana yang dilakukan bank pada umumnya adalah dengan penghimpunan dana kemudian menyalurkannya dalam bentuk pembiayaan berupa pembiayaan modal kerja, investasi, serta pembiayaan konsumtif (Antonio, 2011). Setiap pembiayaan yang diberikan akan memberikan resiko tersendiri bagi pihak bank baik itu berupa resiko kredit, likuiditas , maupun resiko fluktuasi tingkat bunga. Namun resiko yang dihadapi oleh Bank Syariah lebih terfokus pada resiko likuiditas serta resiko kredi dan tidak akan pernah mengalami resiko karena fluktuasi tingkat bunga (Antonio, 2011).

Pada umumnya resiko yang paling potensial dalam pembiayaan di perbankan adalah resiko kredit, yaitu terjadinya non performing financing (pembiayaan bermasalah) dan non performing loan (kredit macet). Resiko kredit muncul jika bank tidak bisa memperoleh kembali cicilan pokok dan bunga dari pinjaman yang diberikan atau investasi yang sedang dilakukan (Andriani, 2015). Data Statistik Moneter dan Fiskal Bank Indonesia menunjukan pembiayaan 
yang diberikan oleh seluruh jenis Bank yang ada di Indonesia mengalami peningkatan yaitu sebesar Rp. 504,494 Miliar di Tahun 2019 meningkat menjadi Rp 513,528 Miliar pada Oktober Tahun 2020 (www.bi.go.id).

Selain persepsi resiko yang patut diperhatikan lagi antara lain ialah pemasaran, pemasaran adalah sebuah awal dari diterimanya produk oleh konsumen. Jika berpijak pada tujuan untuk peningkatan konsumen layanan bank syariah yang beberapa pihak mengatakan masih kurang optimal, maka aspek pemasaran tidak bisa diabaikan begitu saja. Tentu saja dengan asumsi bahwa pengelolaan atau manajemen internal sebuah bank syariah khususnya berkaitan dengan produk yang berbasis syariah. Pemasaran terhadap produk KPR Syariah sangatlah penting, hal ini merupakan kunci suksesnya agar produk KPR Syariah diterima di masyarakat. Bermacam - macam produk dengan berbagai nama tentu sudah dilakukan oleh bank syariah. Pemasaran umumnya langsung pada takaran produk tertentu yang dimiliki oleh bank syariah. Misalnya sebuah bank ada yang mempunyai layanan kredit perumahan syariah, deposito syariah, dan lain sebagainya. Produk - produk bank syariah di Indonesia ini umumnya telah melalui berbagai macam program atau media. Mulai dari media social, pamflet, iklan, bulletin gratis hingga mengikuti pameran - pameran mengenai perbankan syariah khususnya produk KPR Syariah. Intinya program atau strategi pemasaran dilakukan langsung pada sebuah aktivitas untuk menawarkan produk yang spesifik dari sebuah bank (Faiqoh, 2016).

Salah satu usaha yang dilakukan perbankan syariah untuk mengambil hati masyarakat adalah melakukan promosi. Promosi merupakan bagian terpenting dari pemasaran. Pemasaran adalah proses sosial dan manajerial dimana individu dan kelompok mendapatkan kebutuhan dan keinginan mereka dengan menciptakan, menawarkan dan menukarkan produk yang bernilai satu sama lain (Kotler, 2008). Pemasaran dapat dideskripsikan sebagai proses pendefinisian, pengantisipasian, penciptaan serta pemenuhan kebutuhan dan keinginan akan produk dan jasa. Fungsi pemasaran (function marketing) pokok : (1) analisis konsumen, (2) penjualan produk/jasa, (3) perencanaan produk dan jasa, (4) penetapan harga, (5) distribusi, (6) riset pemasaran, (7) analisis peluang, memahami fungsi - fungsi ini membantu para penyusun strategi mengidentifikasi serta mengevaluasi kekuatan dan kelemahan pasar (David, 2009).

Strategi pemasaran adalah pernyataan pokok tentang dampak yang diharapkan akan dicapai dalam hal permintaan pada pasar target tertentu. Pendekatan terinci untuk menerapkan strategi - strategi ini ditentukan lewat program - program pemasaran yang spesifik, seperti program periklanan, program promosi penjualan, program pengembangan produk, serta program penjualan dan distribusi (Guiltinan dan Paul, 1994).

Promosi penjualan adalah perangsan (insentif) ekonomis, hiburan atau informal yang ditawarkan oleh suatu perusahaan kepada para pembeli atau distributor. Walaupun promosi penjualan mungkin berkontribusi dalam membangun kesadaran atau sikap yang menguntungkan terhadap suatu produk, namun penggunaannya terutama adalah lebih untuk mencapai efek penjualan jangka pendek ketimbang jangka panjang (Guiltinan dan Paul, 1994).

Penggunaan strategi promosi yang tepat merupakan salah satu faktor yang sangat mempengaruhi keputusan nasabah dalam memilih produk yang ditawarkan oleh perbankan syariah. Bank menggunakan promosi untuk memicu transaksi, sehingga nasabah tertarik untuk memilih produk yang ditawarkan oleh bank. Dengan promosi yang baik, diharapkan nasabah memilih produk dan mendorong nasabah untuk loyal terhadap produk tersebut. 
Dengan demikian dapat kita lihat bahwa strategi promosi yang tepat dapat meningkatkan jumlah nasabah pada bank syariah tersebut, karena dari promosi tersebutlah pihak bank dapat mempengaruhi para konsumen, mengambil hati konsumen agar tertarik terhadap produk dari bank tersebut. Oleh karena itu peran dari promosi itu sendiri merupakan bagian yang penting dari pemasaran produk bank.

Secara umum calon nasabah yang akan menabung tentu memilih bank yang dapat memberikan keuntungan dan kemudahan. Untuk itu dari pihak bank syariah harus dapat membaca peluang ini serta dapat segera mengidentifikasikan kebutuhan dan keinginan nasabah. Salah satu cara yang dapat dilakukan oleh bank syariah adalah dengan membenahi pelayanannya demi menarik perhatian nasabah. Bentuk pelayan berupa kecepatan, tepat, sopan dan ramah akan membuat nasabah nyaman serta membentuk kepercayaan terhadap bank tersebut bahkan akan merekomendasikan kepada calon - calon nasabah yang lain (Inayah, 2017).

Persaingan untuk memberikan pelayanan yang terbaik terhadap nasabah yang dilakukan oleh masing - masing bank telah menempatkan nasabah sebagai pengambil keputusan. Semakin banyak bank yang beroperasi dengan berbagai fasilitas dan kemudahan yang ditawarkan, membuat nasabah dapat menentukan pilihan sesuai kebutuhannya (Julianti dkk., 2011.). Perilaku konsumen merupakan studi mengenai proses - proses yang terlibat ketika nasabah memilih atau menggunakan produk dan jasa guna memenuhi kebutuhannya. Agar pihak perbankan dapat terus berkembang dan terus berjalan, terutama dalam misi memenuhi kebutuhan konsumen. Maka diperlukan adanya analisis perilaku konsumen sebagai salah satu cara dalam keberhasilan pemasaran yang ditawarkan. Perilaku konsumen merupakan kegiatan individu yang secara langsung terlibat untuk mendapatkan dan menggunakan barang dan jasa, termasuk dalam proses pengambilan keputusan yang memerlukan perancangan terlebih dahulu (Schiffman, 2000).

Sebelum seorang nasabah atau konsumen memberikan keputusan menggunakan suatu produk tertentu, nasabah akan harus mengetahui persepsi resiko dan promosi yang dilakukan oleh bank tersebut. faktor - faktor ini yang mempengaruhi seorang nasabah dalam memilih atau menggunakan suatu produk tertentu yang berasal dari diri nasabah itu sendiri. Berdasarkan penjelasan di atas, peneliti tertarik untuk meneliti perilaku nasabah dalam pengambilan keputusan terhadap produk kredit kepemilikan rumah di bank BUMN. Oleh karena itu peneliti mengambil judul "Analisis Persepsi Resiko, Promosi, dan Margin Terhadap Keputusan Pengambilan Kredit Kepemilikan Rumah (KPR) Syariah (Studi Kasus Bank BRI Syariah Cabang Malang)".

\subsection{KAJIAN PUSTAKA}

\subsubsection{Promosi}

Promosi merupakan salah satu faktor penentuan keberhasilan suatu program pemasaran. Promosi adalah salah satu dari komponen bauran pemasaran yakni aktivitas pemasaran yang berusaha menyebarkan informasi, mempengaruhi dan mengingatkan pasar sasaran atas perusahaan dan produknya agar bersedia menerima, membeli, dan loyal pada produk yang ditawarkan oleh perusahaan yang bersangkutan (Tjiptono, Yogyakarta; Andi, 2008). Ada pendapat dalam pengertian promosi yang dikutip Nela Evelina, promosi adalah 
arus informasi atau persuasi satu arah yang dibuat untuk mengarahkan seseorang kepada tindakan yang menciptakan pertukaran dalam persamaan. Sedangkan menurut Philp Kotler, promosi adalah proses komunikasi suatu perusahaan dengan pihak - pihak yang berkepentingan dan yang akan datang beserta masyarakat (Evelina, Dkk. 2012).

Bisa disimpulkan bahwa promosi adalah usaha - usaha yang dilakukan oleh perusahaan untuk mempengaruhi konsumen supaya membeli produk ataupun menyampaikan berita tentang produk tersebut dengan jalan mengadakan komunikasi dengan para pendengar yang sifatnya membujuk.

\subsubsection{Teori Perilaku Konsumen}

Rahardja dan Manung (2006) menjelaskan, untuk dapat memahami perilaku konsumen harus dimengerti terlebih dahulu beberapa pengertian dan asumsi dasar, yaitu:

Barang - barang adalah benda dan jasa yang dikonsumsi untuk memperoleh manfaat dan kegunaan. Barang yang dikonsumsi mempunyai sifat semakin banyak dikonsumsi semakin besar manfaat yang diperoleh.

Utilitas (utility) Utilitas adalah manfaat yang diperoleh karena mengkonsumsi barang. Utilitas merupakan ukuran manfaat suatu barang dibandingkan dengan barang alternatif lainnya. Utilitas digunakan sebagai dasar pengambilan keputusan oleh konsumen. Utilitas total (total utility) adalah keseluruhan manfaat yang didapat dari seluruh barang yang dikonsumsi. Sedangkan utilitas marjinal (marginal utility) adalah manfaat tambahan yang diperoleh jika suatu pihak menambah konsumsi produk tersebut sebanyak satu unit barang.

Hukum Pertahanan Manfaat yang Semakin Menurun (The Law of Diminishing Marginal Utility) Penambahan konsumsi suatu barang memberi tambahan utilitas yang besar tetapi pertambahan tersebut akan menurun bahkan menjadi negatif seiring dengan dinamika lingkungan dan kondisi yang terjadi.

Konsistensi Preferensi Konsep preferensi berkaitan dengan kemampuan konsumen menyusun prioritas pilihan agar dapat mengambil keputusan. Ada dua sikap yang berkaitan dengan preferensi konsumen, yaitu lebih suka (prefer) dan atau sama - sama disukai (indifference), tanpa sikap ini perilaku konsumen sulit untuk dianalisis. Hal lain agar perilaku dapat dianalisis, konsumen harus memiliki konsistensi preferensi. Bila $A>B$ dan barang $B>C$, maka barang $\mathrm{A}>\mathrm{C}$.

Pengetahuan Sempurna Konsumen diasumsikan memiliki pengetahuan atau informasi yang lengkap mengenai kebutuhannya serta jenis produk apa yang paling mendekati ataau sesuai dengan kebutuhan. Konsumen jenis ini mengerti kualitas barang seperti apa, kapasitas produksi, teknologi yang digunakan, dan harga.

\subsubsection{Teori Pengambilan Keputusan Pembeli}

Pengertian keputusan Pembelian James A.F Stoner mengemukakan, keputusan adalah pemilihan diantara alternatif - alternatif pilihan Hasan, (2002). Definisi ini mengandung tiga pengertian, yaitu: (1) Pilihan berdasar alasan logis atau dengan berbagai pertimbangan. (2) Pilihan terbaik dari beberapa alternatif yang bersifat wajib. (3) Tujuan yang ingin dicapai dan keputusan yang mendekatkan pada tujuan tersebut. 
Perilaku konsumen akan menentukan proses pengambilan keputusan dalam pembelian mereka, proses tersebut merupakan sebuah pendekatan penyesuaian yang terdiri dari lima tahap yang dilakukan oleh konsumen, kelima tahap tersebut adalah pengenalan masalah, pencarian informasi, penilaian alternatif, membuat keputusan, dan perilaku pasca pembelian (Kotler, 2008).

Dalam setiap proses pengambilan keputusan hendaknya memahami empat komponen dari sebuat pengambilan keputusan (Hasan, 2002) yaitu: (1) Tujuan pengambilan keputusan. (2) Identifikasi alternatif keputusan untuk menemukan solusi. (3) Perhitungan mengenai faktor - faktor tidak terduga. (4) Sarana atau alat untuk evaluasi hasil dari suatu pengambilan keputusan.

Proses Keputusan Pembelian Menurut Kotler (2008), ada lima tahap proses keputusan pembelian, yaitu: (1) Pengenalan masalah proses ini dimulai dari saat pembeli menyadari adanya masalah dalam kebutuhanya. Pembeli menyadari adanya perbedaan antara kondisi real dengan kondisi yang diinginkan. Kebutuhan ini dapat disebabkan oleh rangsangan internal maupun eksternal. (2) Pencarian informasi seorang konsumen yang terdorong akan kebutuhanya akan mencari informasi lebih lanjut. Hal ini dapat dibedakan dalam dua tingkat, yaitu keadaan tingkat pencarian informasi yang sedang bisa disebut perhatian yang meningkat dan pencarian informasi secara aktif. (3) Penilaian alternatif konsumen memproses informasi tentang pilihan produk untuk membuat keputasn akhir. Ada beberapa proses dalam evaluasi keputusan. Kebanyakan model dari proses ini bersifat kognitif, yaitu konsumen menilai suatu produk berdasarkan pertimbangan yang rasional dan sadar. Konsumen mungkin mengembangkan seperangkat kepercayaan produk tentang dimana setiap produk mempunyai ciri masing - masing. Dari kepercayaan ini menumbulkan citra produk. (4) Keputusan membeli setelah tahap evaluasi, dimana konsumen membentuk preferensi terhadap produk yang telah dihimpun dalam niat membeli dan yang disukai. Kemudian konsumen memilih produk yang paling disukai. (4) Perilaku paska pembelian sesudah pembelian terhadap suatu produk, maka konsumen akan mengalami tingkat kepuasan atau ketidakpuasan. Konsumen tersebut juga akan terlibat dalam tindakan pasca pembelian dan penggunaan produk yang akan menarik minat pasar.

\section{Metode}

Penelitian ini menggunakan pendekatan kuantitatif dengan untuk menganalisis pengaruh variabel bebas yaitu Promosi (X1) dan Margin (X2) terhadap variabel terikat yaitu keputusan nasabah mengambil KPR Syariah di BSI kantor cabang soekarno-hatta malang(Y). Untuk menganalisis pengaruh variabel bebas terhadap variabel terikat, di dalam penelitian ini menggunakan metode regresi berganda dengan metode OLS (Ordinary Least Square) serta uji asumsi - asumsi klasik. Metode OLS ini bertujuan meminimumkan jumlah kuadrat error.

\section{Hasil dan Pembahasan}

\subsection{Pengaruh Promosi Terhadap Pengambilan KPR Syariah}

Berdasarkan hasil uji f pada tabel 4.9 hasil regresi linier berganda, p value variabel promosi 0.0000 dan dapat disimpulkan bahwa variabel promosi berpengaruh terhadap keputusan pengambilan KPR Syariah secara bersama - sama (simultan), berarti hasil tersebut menunjukan bahwa promosi dan margin (margin) secara bersama - sama berpengaruh signifikan terhadap keputusan pengambilan KPR Syariah. 
Hasil analis kedua, berdasarkan uji t pada tabel 4.8 hasil regresi linier berganda, yaitu $\mathrm{p}$ value 0.0000 dan dapat disimpulkan bahwa variabel promosi berpegaruh signifikan terhadap keputusan pengambilan KPR Syariah secara individu (parsial). Hal ini sejalan dengan penelitian Denny Daud (2013) yang berjudul Promosi dan Kualitas Layanan Pengaruh terhadap Keputusan Konsumen menggunakan Jasa Pembiayaan pada PT. Bess Finnance Manado. Hasil penelitian menunjukan variabel promosi berpengaruh secara positif dan signifikan terhadap keputusan konsumen.

Penelitian ini juga didukung oleh hasil dari peneliti lain yaitu Achmad Muzakky (2019) yang berjudul Pengaruh Regulitas dan Promosi terhadap Pengambilan Keputusan Pembiayaan KPR Griya IB Hasanah BNI Syariah KC Bukit Darmo Boulevard. Hasil penelitian ini berpengaruh secara positif dan siginifikan terhadap keputusan pembiaayaan KPR Griya ib Hasanah BNI Syariah KC Bukit Darmo Bouevard Surabaya.

Hal ini sesuai dengan teori yang dikutip dari M. Rifa'I dan Hamidi (2017), "Promosi merupakan kombinasi strategi yang baik dari variable periklanan, personal selling, dan alat alat promosi yang lain. Semuanya dirancang untuk mencapai tujuan akhir program penjualan. Dalam meningkatkan penjualan dan menghadapi persaingan yang tajam antar perusahaan dalam berbagai industry, maka setiap perusahaan perlu melaksanakan kegiatan periklanan karena potensi jumlah konsumen yang meningkat". Untuk itu Bank Syaria Indonesia juga melakukan promosi lainnya dengan menggunakan media cetak berupa spanduk yang di letakkan pada beberapa lokasi untuk lebih mengenalkan produk BSI Syariah ke berbagai kalangan yang merupakan pengguna jalan. Dalam penelitian ini juga di dukung oleh pendapat Kotler dan Armstrong yang menyatakan bahwa promosi adalah kegiatan yang mengkonsumsikan keunngulan produk dan membujuk (persuading) para pembeli untuk bersedia membeli produk tersebut.

\subsection{Pengaruh Margin Terhadap Keputusan Pengambilan KPR Syariah}

Hasil analisis yang pertama yaitu secara bersama - sama (simultan) menunjukan bahwa pengaruh variabel margin terhadap keputusan pengambilan kredit kepemilikan rumah syariah apabila dilihat dari nilai signifikasinya memiliki pengaruh yang signifikan. Berarti hasil tersebut menunjukan Margin dan Promosi berpengaruh secara simultan terhadap keputusan pengambilan KPR Syariah di BSI Kota Malang.

Hasil analisis yang kedua yaitu secara individu (parsial) menunjukan bahwa pengaruh variabel margin (margin) terhadap keputusan pengambilan KPR Syariah di Bank BSI kantor cabang soerkarno - hatta apa bila dilihat dari nilai signifikansinya tidak memiliki pengaruh signifikan. Berarti hal ini menunjukan bahwa variabel margin tidak berpengaruh terhadap keputusan pengambilan KPR Syariah di Bank BSI kantor cabang soekarno - hatta Kota Malang secara parsial. Hal ini justru berbanding terbalik dengan peneliti sebelumnya Hidayah dam Prabawani (2016) yang menyatakan bahwa margin di bank yang mereka teliti lebih tinggi dari bank yang lain tetapi dengan margin yang tinggi malah diikuti dengan pengambilan KPR yang tinggi.

Perbedaan ini disebabkan hal yang terjadi dilapangan, dikarenakan nasabah yang ingin mengambil KPR Syariah dilapangan lebih cenderung mengambil KPR dikarenakan kemampuan setiap individu mampu atau tidak membayar deposito di awal di cicilan setiap bulannya. 


\subsection{Pengaruh Promosi dan Margin Terhadap Pengambilan KPR Syariah}

Berdasarkan hasil uji F (simultan) yang bisa dilihat pada tabel 4.9 hasil analisis linier berganda, nilai dari p value variabel promosi dan margin 0.000 yang lebih kecil dari 0,1 sehingga dapat disimpulan variabel bebas promosi dan margin berpengaruh signifikan secara simultan terhadap keputusan pengambilan KPR Syariah di Bank Syariah Indonesia KC Suekarno - hatta. Dengan demikian hipotesis yang menyebutkan "Adanya Pengaruh Promosi dan Margin secara simultan terhadap Keputusan Pengambilan Kredit Kepemilikan Rumah (KPR) Syariah di Bank Syariah Indonesia KC Soekarno - hatta" dapat diterima. Besarnya pengaruh dari kedua variabel tersebut sebesar $57.46 \%$ dan sisanya $46.52 \%$ yang dipengaruhi oleh variabel lain yang tidak dikaji dalam penelitian ini.

Hasil penelitian ini juga didukung oleh penelitian Achmad Muzakky (2019) yang berjudul "Pengaruh Regulitas dan Promosi terhadap Pengambilan Keputusan Pembiayaan KPR Griya IB Hasanah BNI Syariah KC Bukit Darmo Boulevard". hasil penelitian ini berpengaruh secara positif dan siginifikan terhadap keputusan pembiaayaan KPR Griya ib Hasanah BNI Syariah KC Bukit Darmo Bouevard Surabaya.

Selain itu hasil penelitian ini juga di dukung oleh Novitasari dan Hidayati (2020) yang berjudul "Pengaruh Citra Perusahaan, Kualitas Layanan, Margin, dan Promosi Terhadap Keputusan Pengambilan Kredit Rumah PT. Bank Tabungan Negara Cabang Gresik". Hasil penelitian ini berpengaruh positif dan signifikan terhadap keputusan pengambilan kredit.

Lalu untuk hasil dilapangan sendiri, para nasabah juga memilih mengambil kredit kepemilikan rumah dikarenakan tawaran promosi yang dilakukan oleh pihak bank maupun pihak perumahan, kebanyakan mereka tertarik setelah mendengar promosi mereka tentang kredit kepemilikan rumah yang ditawarkan. Jadi dapat disumpukan bahwa promosi berperan besar dalam tindakan nasabah untuk mengambil keputusan membeli kredit kepemilikam rumah (KPR) Syariah, lalu diikuti dengan nilai margin (margin) yang sudah disepakati di awal atau akad diawal.

\section{Simpulan}

Berdasarkan analisis yang telah dilakukan pada bab-bab sebelumya, berikut peneliti lampirkan kesimpulan dari penelitian ini.

Terdapat pengaruh yang siginifikan secara parsial antara promosi terhadap keputusan kpengambilan kredit kepemilikan rumah (KPR) Syariah di Bank Syariah Indonesia KC soekarno - hatta. Karena nasabah dipengaruhi oleh promosi yang dilakukan bank tersebut agar mengambil kredit kepemilkan rumah (KPR) Syariah dibank tersebut.

Tidak terdapat pengaruh yang signifikan secara parsial antara margin (margin) terhadap keputusan pengambilan kredit kepemilikan rumah (KPR) Syariah di Bank Syariah Indonesia KC soekarno-hatta. Ini disebebkan hasil wawancara dengan responden kebanyakan mereka mengambil KPR dikarenakan promosi deposit dan cicilan yang kecil di awal dan juga diakrenakan peneliti menelit KPR syariah yang bersifat subsidi atau bunganya sama disetiap nasabah, sehingga nasabah memilih mengambil KPR dikarenakan nasbah mampu membayar cicilan dan deposit diawal. 
Terdapat pengaruh yang signifikan secara simultan antara promosi dan margin terhadap pengambilan kredit kepemilikan rumah (KPR) Syariah di Bank Syariah Indonesia KC soekarno - hatta. Karena kebanyakan responden menjawab mengambil keputusan untuk mengambil KPR Syariah di Bank tersebut lantaran baru mengetaui promo yang diberikan oleh bank, promo yang dimaksud seperti kredit kepemilikan rumah (KPR) Syariah yang bersubsidi.

\section{Daftar Rujukan}

Astuty, P., \& Nurjanah, N. (2018). Analisis Pengaruh Financing to Deposit Ratio (FDR), Non Performing Financing (NPF), Suku Bunga Dan Bank Size Terhadap Pembiayaan KPR Syariah (Studi Kasus Pada Bank Umum Syariah di Indonesia dan Malaysia Periode 2010-2016). JURNAL EKONOMI, 20(3), 286299.

Cholid, I., \& Artina, N. (2017) Analisis Pengaruh Tingkat Bunga Pinjaman dan Pelayanan terhadap keputusan pengambilan Kredit Perumahan Rakyat (KPR) pada Bank BTN Cabang Palembang.

Daud, D. (2013). Promosi dan kualitas layanan pengaruhnya terhadap keputusan konsumen menggunakan jasa pembiayaan pada PT. Bess Finance Manado. Jurnal EMBA: Jurnal Riset Ekonomi, Manajemen, Bisnis dan Akuntansi, 1(4).

Faiqoh, R. (2016). Analisis Strategi Pemasaran KPRS di Bank Muamalat Cabang Kudus. Jurnal Iqtishadia, 6(2), 279-291.

Fitrian, B. (2017). Faktor-faktor Yang Mempengaruhi Preferensi Nasabah Terhadap Produk Pembiayaan Murabahah Kredit Pemilikan Rumah (KPR) Syariah (Studi Kasus Di Bank Syariah Mandiri Cabang Surabaya Sungkono) (Doctoral dissertation, Universitas Brawijaya).

Guiltinan, P. Joseph da Gorden W Paul. (1994). Strategi dan Program Manajemen Pemasaran. Terjemahan oleh Agus Maulana. Jakarta: Penerbit Erlangga

Hasan, Iqbal. (2002). Pokok-pokok Materi Metodologi Penelitian dan Aplikasinya, Jakarta: Ghalia Indonesia.

Hawkins, D., I. dan Mothersbaugh, D., L. (2010). Consumer Behavior: Building Marketing Strategy, 11th Edition. McGraw Hill: Irwin.

Heykal, M. (2014). Analisis Tingkat Pemahaman KPR Syariah pada Bank Syariah di Indonesia: Studi Pendahuluan. Binus Business Review, 5(2), 519-526.

Hidayat, G. (2017). Analisis Faktor-Faktor Yang Mempengaruhi Keputusan Permintaan KPR Pada Bank Syariah Di Kabupaten Sumedang. Coopetion, VIII, 129-137.

Hidayah, L., \& Prabawani, B. (2016). Pengaruh Margin, Pelayanan Dan (Studi Pada Nasabah Pt Bank Tabungan Negara Kantor Cabang Semarang). Jurnal Ilmu Administrasi Bisnis, 5(4), 458-465. https://ejournal3.undip.ac.id/index.php/iiab/article/view/13592

Karim, Adiwarman. (2021). Ekonomi Mikro Islami. Jakarta: Rajawali Press.

Kotler, P dan Amstrong, G. (2008). Prinsip-Prinsip Pemasaran. Jakarta: Penerbit Erlangga.

Manurung, M. (2004). Uang, perBankan, dan ekonomi moneter: kajian kontekstual Indonesia: Berdasarkan UU no. 7/1992 sebagaimana diubah dengan UU no. 10/1998, UU no. 3/2004 (Perubahan atas UU no. 23/1999): dilengkapi arsitektur perBankan Indonesia (API). Penerbitan Fakultas Ekonomi, Universitas Indonesia.

Malhotra, N., Hall, J., Shaw, M., \& Oppenheim, P. (2006). Marketing research: An applied orientation. Pearson Education Australia.

Muhamad, Salim. (2009). Analisis faktor-faktor yang mempengaruhi pengambilan keputusan kreditor dalam memilih KPR Syariah. Fakultas Ekonomi Program Ekstensi Depok.

Muzakkiy, A. (2019). Pengaruh Religiusitas dan Promosi Terhadap Pengambilan Keputusan Pembiayaan KPR Griya Ib Hasanah BNI Syariah KC Bukit Darmo Boulevard Surabaya (Doctoral dissertation, UIN Sunan Ampel Surabaya).

Nasional, K. P. (2017). Universitas Negeri Malang. Pedoman Penulisan Karya Ilmiah. Edisi ke enam.

Pamungkas, B. A. (2016). Pengaruh promosi di media sosial dan word of mouth terhadap keputusan pembelian (Studi kasus pada Kedai Bontacos, Jombang). Jurnal Komunikasi, 10(2), 145-160.

Peter dan Jerry. (2006). Perilaku Konsumen dan Strategi Pemasaran. Jakarta: Erlangga. 
Jurnal Ekonomi, Bisnis dan Pendidikan, 1(7), 2021, 638-647

Pt, R., Tabungan, B., \& Cabang, N. (2020). Jurnal Mahasiswa Manajemen, Volume 01 Nomor 01 Tahun 2020. 01.

Putri, D. E. (2017). Strategi dan Peran Customer Service dalam Upaya Meningkatkan Jumlah Nasabah Tabungan Mabrur Di Bank Syariah Mandiri Kc Ajibarang Banyumas (Strategy and The Role of Customer Service in an Effort to Increase Customer Quantity on Savings Mabrur at Bank Syariah Mandiri Branch Office's Ajibarang Banyumas) (Doctoral dissertation, IAIN Purwokerto).

Rahardja, Prathama, dan Manurung, Mandala. (2006). Teori Ekonomi Mikro Suatu Pengantar. Jakarta: Lembaga Penerbit Fakultas Ekonomi Universitas Indonesia.

Rifa'i, M., \& Hamidi. (2017). Efektivitas Promosi Online Dalam Pengambilan Keputusan Oleh Konsumen. OPTIMA (Jurnal IIlmiah Bidang Agribisnis Dan Ekonomi, 1(2), 67-73.

Schiffman dan Kanuk. (2007). Perilaku Konsumen. Jakarta: Indeks.

Sugiyono, (2002). Metode Penelitian Administrasi (Cetakan ke 9). Bandung: Alfabeta.

Sugiyono. (2010). Statistika Untuk Penelitian. Bandung: CV. Alfabeta.

Sugiyono, P. D. (2017). Metode Penelitian Bisnis: Pendekatan Kuantitatif, Kualitatif, Kombinasi, dan R\&D. Penerbit CV. Alfabeta: Bandung.

Sukmawati, E. (2020). Pengaruh Pendapatan Dan Margin Terhadap Keputusan Pengambilan Kpr Pada Pt Bank Tabungan Negara (Persero) Tbk Cabang Prabumulih. Islamic Banking: Jurnal Pemikiran Dan Pengembangan Perbankan Syariah, 5(2), 53-72. https://doi.org/10.36908/isbank.v5i2.116

Suryani, Tatik. (2008). Perilaku Konsumen Implikasi pada Strategi Pemasaran. Yogyakarta: Graha Ilmu

Itsnaini, P. R. DAMPAK COVID-19 TERHADAP LEMBAGA KEUANGAN SYARIAH (PERBANKAN SYARIAH).

Yahya, A. (2016). Analisis Faktor - Faktor Yang Mempengaruhi Keputusan Nasabah Memilih Kredit Pemilikan Rumah (KPR) Syariah (Studi Pada KPR Syariah Bank BTN Syariah Cabang Malang). Jurnal Ilmiah, 10(2), $1-94$.

Zainuddin, Z., Hamja, Y., \& Rustiana, S. H. (2017). Analisis Faktor dalam Pengambilan Keputusan Nasabah Memilih Produk Pembiayaan Perbankan Syariah (Studi Kasus pada PT Bank Syariah Mandiri Cabang Ciputat). Jurnal Keuangan Dan Perbankan, 13(1), 55-76. 